\title{
Américo Negrette and Huntington's disease
}

\author{
Mariana Moscovich', Renato P. Munhoz' , Nilson Becker', \\ Egberto Reis Barbosa², Alberto J. Espay ${ }^{3}$, \\ Roberto Weiser ${ }^{4}$, Hélio A.G. Teive ${ }^{1}$
}

\begin{abstract}
The authors present a historical review of the seminal clinical contribution of Professor Américo Negrette, a Venezuelan neurologist, to the evolution of scientific knowledge about Huntington's disease.
\end{abstract}

Key words: Américo Negrette, Huntington's disease, chorea, huntingtin, CAG.

\section{Américo Negrette e a doença de Huntington}

\section{RESUMO}

Os autores apresentam uma revisão histórica sobre a magistral contribuição clínica do Professor Américo Negrette, neurologista venezuelano, na evolução do conhecimento científico sobre a doença de Huntington.

Palavras-chave: Américo Negrette, doença de Huntington, coréia, Huntingtina, CAG.

Huntington's disease (HD) is a neurodegenerative disorder with an autosomal dominant inheritance pattern, resulting from an expanded and unstable trinucleotide repeat in the IT15 gene on chromosome 4 that encodes a protein called huntingtin ${ }^{1,2}$.

The prevalence of HD in the Caucasian population ranges from $0.5-1$ in 10,000 . Mean age at onset is between 35 and 50 years, and the main manifestations are involuntary movements, especially chorea, behavioral and psychiatric disturbances, and dementia. The disease progresses inexorably and has a mean duration of 17-20 years. No effective treatment is currently available ${ }^{1-3}$.

Among the great strides made in the search for greater understanding of HD was the discovery of the gene in 1993 in a cooperative research effort in Venezuela known as the Huntington's Disease Collaborative Research Group ${ }^{4}$. This effort was influenced by the pioneering work of a Venezuelan physician, Dr. Américo Negrette, who is the subject of this review.

\section{Américo Negrette}

Américo Negrette (1924-2003), a Venezuelan physician, biochemist, artist and poet (Fig 1and 2), was born in La Cañada, Venezuela ${ }^{5}$.

Negrette graduated in medicine in 1949 at the Central University of Venezuela.

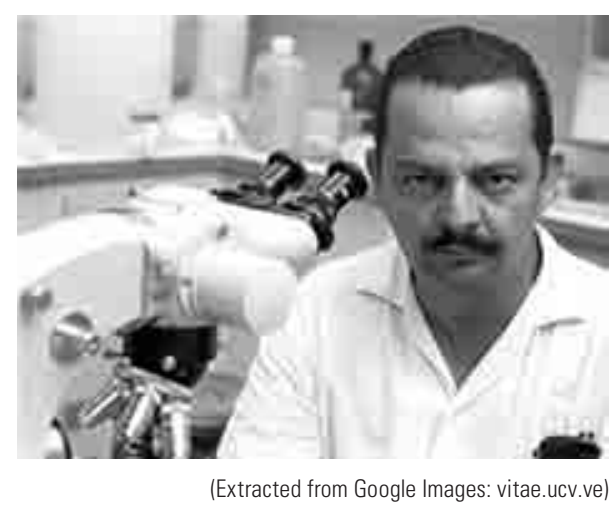

Fig 1. Professor Américo Negrette (1924-2003).
Hélio A.G. Teive

Rua General Carneiro 1103/102 80060-150 Curitiba PR - Brasil E-mail: hagteive@mps.com.br

Received 10 April 2011 Received in final form 16 April 2011 Accepted 27 April 2011
${ }^{1}$ Movement Disorders Unit, Neurology Service, Internal Medicine Department, Hospital de Clínicas, Federal University of Paraná, Curitiba PR, Brazil; ${ }^{2}$ Movement Disorders Unit, Department of Neurology, São Paulo University Medical School, São Paulo SP, Brazil; ${ }^{3}$ Gardner Family Center for Parkinson's Disease and Movement Disorders, Department of Neurology, University of Cincinnati, Cincinnati, Ohio, USA; ${ }^{4}$ Neurology Department, Instituto de Clinicas, Tamanaco, Caracas, Venezuela. 
While working as a rural practitioner in San Francisco, Maracaibo, in 1952, he was instructor in clinical medicine in the Faculty of Medicine at the University of Zulia. During his stay in San Francisco, Negrette found patients in the streets with a peculiar gait disorder and involuntary movements known by the local people as "Sanviteros". In fact, these patients had a hereditary disease, known locally as "el mal de San Vito", later known as $\mathrm{HD}^{3,5-7}$.

In 1955 Negrette presented the study "Huntington chorea: a first communication" during the $6^{\text {th }}$ Medical Sciences Congress in Venezuela. In 1963 he published the book "Huntington's chorea", containing clinical descriptions of several patients ${ }^{6}$.

Later, Negrette received graduate training in neurology at the Institute for Clinical and Medical Research in Madrid. Following this, he was appointed professor of clinical neurology in the Department of Medicine at the University of Zulia and became founding director of the Clinical Research Institute at the same university ${ }^{5}$.

\section{Negrette's book on Huntington's disease}

Negrette's book on HD, published in 1963, has 226 pages and eight chapters, covering clinical description of several cases, their semiology, pathophysiology of choreas, basic genetics, diagnosis, additional tests and hereditary aspects, as well as social, economic and environmental aspects and bibliographical references ${ }^{6}$.

The two most important chapters are "Clinical histories" and "a compendium of clinical histories" in which the author discusses the clinical manifestations of $\mathrm{HD}^{6}$.

The chapter "Clinical hstories" describes the anamnesis and general and neurological examination of 39 chorea patients (17 male and 22 female). The clinical histories of a further 29 at-risk individuals without chorea (13 male and 16 female) are also discussed ${ }^{6}$.

In the chapter "A compendium of clinical histories" Negrette summarizes the main abnormalities found on examination. The chapter is illustrated with figures, tables and photographs, and emphasis is placed on the main abnormalities observed on neurological examination, particularly involuntary movements (chorea and ataxia), muscle hypotonia, abnormal deep tendon reflexes, language disturbances, and behavioral/cognitive disturbances ${ }^{6}$.

Overall, Negrette's book on HD provides an extensive basic clinical assessment of the cases he studied, which served as the basis for further international genetic studies ${ }^{6}$.

The connection between Negrette's work and Dr. Wexler from the USA

At the Centennial Symposium on HD in Ohio, USA, in 1972, a former student of Negrette, Dr. Ávila-Girón,

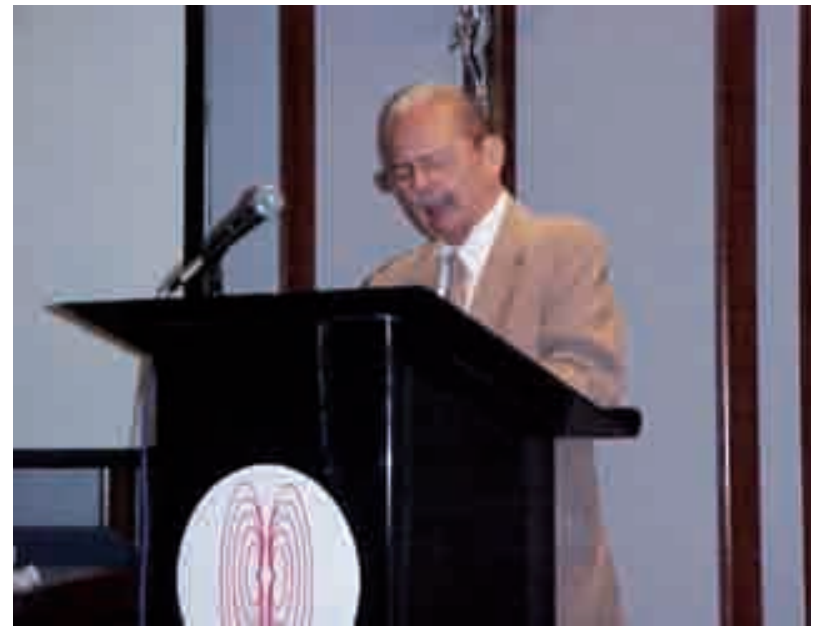

Personal archive of Roberto Weiser.

Fig 2. Professor Américo Negrette during the celebration of the opening of AVEHUN (Asociación Venezolana de Huntington) in 2000.

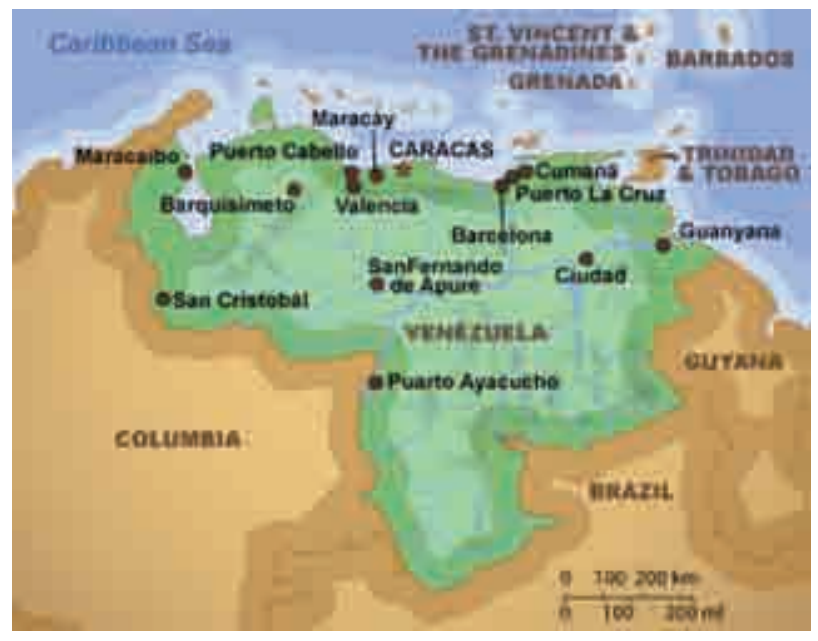

(Extracted from Google Images).

Fig 3. Venezuela Map and Maracaibo Island.

presented a series of cases of patients with HD in the Maracaibo region of Venezuela (Fig 3). Ávila-Girón's data were published in 1973 in a book edited by Barbeau et al. ${ }^{8}$. In fact it was Barbeu himself who visited Venezuela and confirmed the diagnosis. Because of the large number of cases in areas close to Lake Maracaibo, where there were families in which both parents were HD sufferers, it was agreed that a study would be carried out to evaluate possible homozygotes ${ }^{7,8}$.

However, there can be no doubt that the main interest in studying Venezuelan patients with HD came from the Hereditary Disease Foundation, an organization coordinated by Dr. Milton Wexler after his wife, Alice Wexler, developed confirmed HD. Dr. Nancy Wexler, Alice Wexler's daughter, played a major role in research into $\mathrm{HD}^{7}$. 
With the support of the United States National Institute of Mental Health, Dr Nancy Wexler started a genetic study of HD patients in Maracaibo, which culminated in the discovery of the HD gene $e^{3,7,9}$.

\section{Discovery of the gene for Huntington's disease}

The Venezuelan HD kindreds were first described by Negrette and represented the largest and best characterized HD population in the world. Most of the families live in the Lake Maracaibo region in the state of Zulia, Venezuela. The Venezuelan kindreds were highly heterogeneous. While the majority were Hispanic, their genetic and phenotypic heterogeneity was the result of miscegenation with European sailors and traders, with some $\mathrm{Na}$ tive American admixture ${ }^{3,5-8}$.

In 1979 Nancy Wexler visited Venezuela for the first time, originally with the intention of finding a homozygote. Once she began fieldwork in 1981, the recombinant DNA revolution had begun and she and other researchers changed their plans, deciding instead to carry out genetic linkage studies in these families. The group collected extensive pedigrees - who is related to whom which were essential for mapping the HD gene to a chromosome. The Venezuelan Pedigree proved to be of great value, not only for research on HD, but also for understanding inheritance in general. These family trees were perfectly structured for use in genetic linkage studies ${ }^{3-5,7,9}$. The research effort culminated in 1983 with the mapping of the HD gene to chromosome 4p16.3, by Gusella et al. ${ }^{10}$.

The Huntington's Disease Collaborative Research Group, which involved six research groups (four from the USA, two from the UK) and more than 150 investigators, found the defective HD gene in 1993. This finding was published in the seminal paper "A novel gene containing a trinucleotide repeat that is expanded and unstable on Huntington's disease chromosomes" in the prestigious journal Cell ${ }^{4}$.

The huntingtin mutation is an unstable trinucleotide (CAG) repeat expansion in the ORF of exon 1 of the gene and is related to the expression of an expanded polyglutamine repeat in the huntingtin protein ${ }^{1-3,7,9}$.

Since the discovery of the gene, HD has been defined as an autosomal dominant neurodegenerative disease caused by a CAG repeat expansion mutation, i.e., a polyglutamine disease $\mathrm{e}^{1,2,7,9,10}$.

\section{Conclusion}

The enormous progress in HD research in recent years with the mapping of the gene, the identification of the mutation and the current definition of the condition as a polyglutamine disease, owes much to the masterly clinical study carried out by professor Américo Negrette in Venezuela in the 1950s.

ACKNOWLEDGMENTS - The authors would like to thank Mr. Colin Bowles, for his assistance with the English revision of this manuscript.

\section{REFERENCES}

1. Ross CA, Tabrizi SJ. Huntington's disease: from molecular pathogenesis to clinical treatment. Lancet Neurol 2011;10:83-98.

2. Cardoso F. Huntington's disease and other choreas. Neurol Clin 2009;27: 719-736.

3. Harper PS. Huntington's disease: a historical background. In: Bates G, Harper PS, Jones L (Eds). Huntington's disease. Third Edition, Oxford University Press, Oxford, UK, 2002:113-158.

4. Huntington's Disease Collaborative Research Group. A novel gene containing a trinucleotide repeat that is expanded and unstable on Hunting ton's disease chromosomes. Cell 1993;72:971-983.

5. Okun MS, Thommi N. Américo Negrette (1924 to 2003) diagnosing Huntington disease in Venezuela. Neurology 2004;63:340-343.

6. Negrette A. Corea de Huntington. Segunda Edicion, Maracaibo: Talleres Graficos de la Universidad del Zulia, 1963.

7. Harper PS, Jones L. Huntington's disease: genetic and molecular studies. In: Bates G, Harper PS, Jones L (Eds). Huntington's disease. Third Edition, Oxford University Press, Oxford, UK, 2002:3-27

8. Avila-Girón R. Medical and social aspects of Huntington's chorea in the state of Zulia, Venezuela. In: Barbeau A, Chase TN, Paulson GW (Eds). Advances in Neurology. New York: Raven-Press, 1973: 261-266.

9. Wexler NS, Lorimer J, Porter J, et al. Venezuelan kindreds reveal that genetic and environmental factors modulate Huntington's disease age of onset. Proc Natl Acad Sci USA 2004;101:3498-3503.

10. Gusella JF, Wexler NS, Connealy PM, et al. A polymorphic DNA marker genetically linked to Huntington's disease. Nature 1983;306:234-238. 